\title{
THE 'VERENIGING' AT ANGKOR: FOUR SANDSTONE SCULPTURES FROM CAMBODIA
}

The Society's collection of ancient Khmer art from Cambodia is based on the acquisition of four exceptional stone sculptures from Angkor in the early 1930s. Through the travel diaries of the Society's first president H.K. Westendorp, and by consulting a complete series of letters now kept in the archives of the École française d'Extrême-Orient (EFEO) in Paris, it is now possible to reconstruct the precise details of this historic purchase.

In 1928, the committee of the Society established an Acquisition Fund for the purchase of outstanding examples of Asian art for future display in a permanent museum collection. In less than six months, a remarkable sum of 150,000 guilders was collected for this purpose through private donation alone. $^{2}$ In order to use these funds effectively, the Curator of the Society's collection, H.F.E. Visser (1890-1965) and its President, H.K. Westendorp (1868-1941) both embarked on tours of Asia, meeting up together in Japan for an extremely fruitful visit in the Autumn of $1930 .{ }^{3}$ On 1 st December, Westendorp left Visser and Japan for Shanghai in the ever-present company of his wife (fig. 1), the artist Betsy Westendorp-Osieck (1880-1968).

His intended destination was Indochina, in particular the ruins of the great city of Angkor in Cambodia.

For this part of his journey, Westendorp came well-prepared. Cambodia at this time was a Protectorate of France and part of the wider administration of French Indochina or Indochine française. Before leaving Europe, Westendorp had been given a letter of introduction from his friend, Raymond Koechlin (1860-1931), one of the founders of the Société des Amis du Louvre and President of the Conseil des Musées Nationaux. This letter (EFEO 3 annexe) was addressed to George Cœdès (1886-1969), then Director of the EFEO in Hanoi, who was responsible for overseeing the archaeological and museum service throughout Indochina. Moreover, in the summer of 1930, Westendorp had already met and discussed his plans with Henri Marchal (1876-1970), the head of the Conservation d'Angkor, who had been travelling as a guest of the Dutch Archaeological Service in Java and Bali. Marchal sent a telegram to Cœdès on 4th December to inform him of Westendorp's imminent arrival (EFEO 1) and Cœdès immediately wrote a letter (EFEO 1a) to the Governor General of Indochina, Pierre Marie Antoine Pasquier (1877-1934 - known by his nom de plume of 'Gougal'), to tell him about Westendorp's visit and to request approval in principal for his request to acquire sculptures for the museum in Amsterdam. Official permission was granted by the office of the Governor General on 20th December (EFEO 2).

\section{The Westendorps in Cambodia}

However, all these careful plans and preparations appeared to have been in vain when, after leaving Shanghai on the 6th December, H.K. Westendorp access 

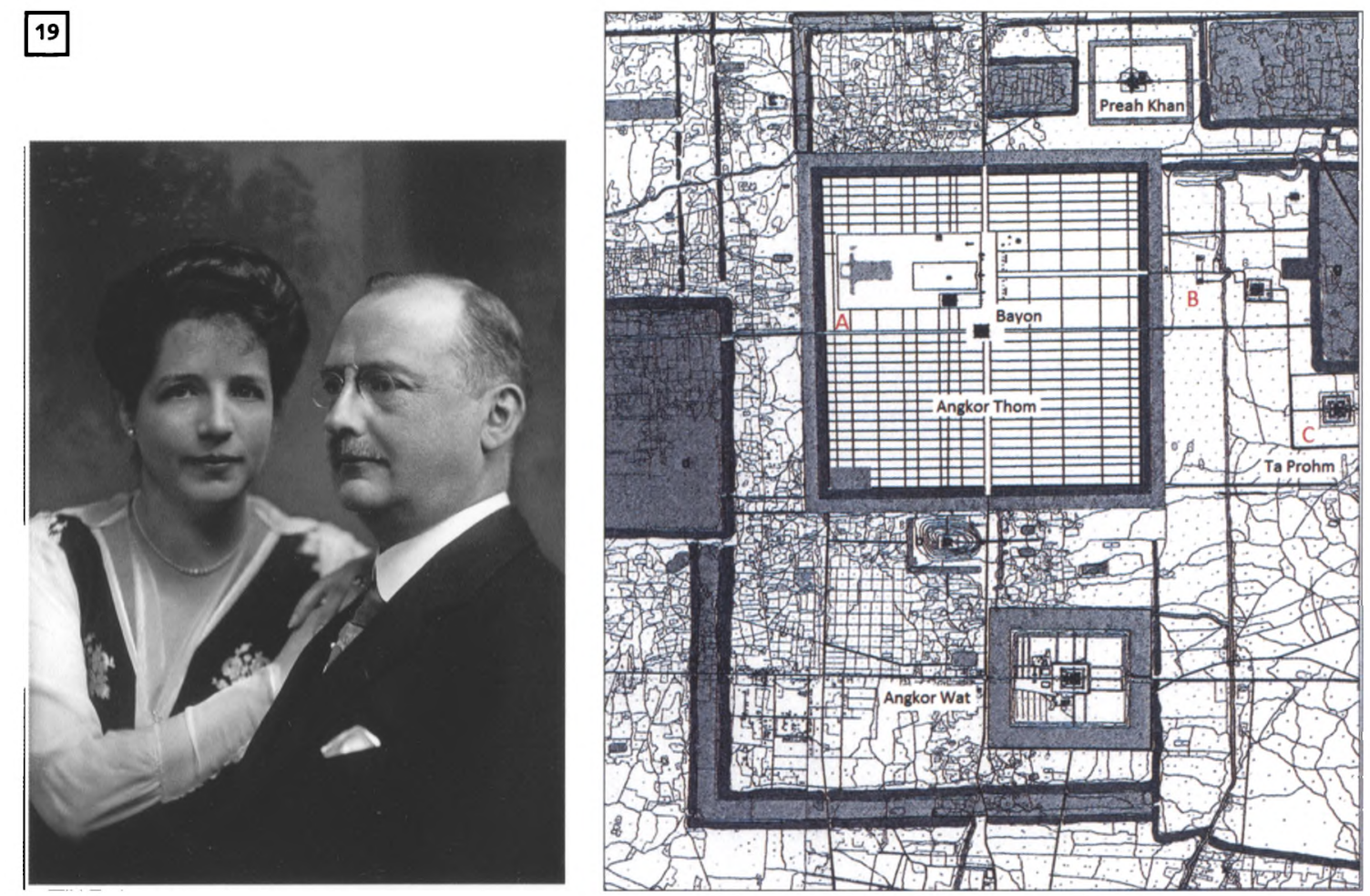

Fig. 1

Betsy WestendorpOsieck \& Herman Karel Westendorp.

Fig. 2

Map of the central Angkor region (adapted from Gaucher 2004: Fig. 6, based on JICA $1 / 5,000$ ) fell seriously ill with stomach pains. Instead of travelling to Cambodia, he was forced to return to Singapore, where he was admitted to the General Hospital on 18th December. Although the doctors could find no diagnosis for his illness, the pain gradually subsided and after a stay of ten days in hospital he was cleared to continue his journey. On the 27th December 1930, he and his wife left Singapore on board the André Lebon, arriving in Cambodia on the 30th December. After visiting the Musée Albert Sarraut (now the National Museum in Phnom Penh), they travelled by car to Angkor on 1st January 1931, stopping at Kompong Thom on the way for lunch. Their home during the visit was to be the famous Hôtel des Ruines, situated in the Angkor archaeological park directly opposite the main western causeway and entrance to Angkor Wat (fig. 2). These details of their journey and stay at Angkor can be reconstructed from the diaries of H.K. Westendorp, which have been preserved intact for this section of his tour of Asia. The diaries provide short descriptions of their visit to the temples and of their later reception by Henri Marchal, whom they had met the previous summer in Java and Bali:

Thursday 8th January. Marchal came to collect us at 7 o'clock.

We went with him to the Bayon, and thus saw far more, including the great faces from close up. For photos, the sun was really not yet strong enough. Afterwards to Preah Khan, where we clambered round to the innermost sanctuary. At the Porte la Victoire 2 photos, I think only the last good. Afterwards to the dépot. Piles of heads, torsos etc. The most beautiful are for Paris, or reserved for Phnom Penh and Hanoi, but I nevertheless select 3 pieces $-\mathrm{a}$ big head a piece with 3 heads $_{6}$ and $\mathrm{a}_{1: 16: 14 \mathrm{AM}}$ figure - that I hope to get for the Museum. That would be something! access 


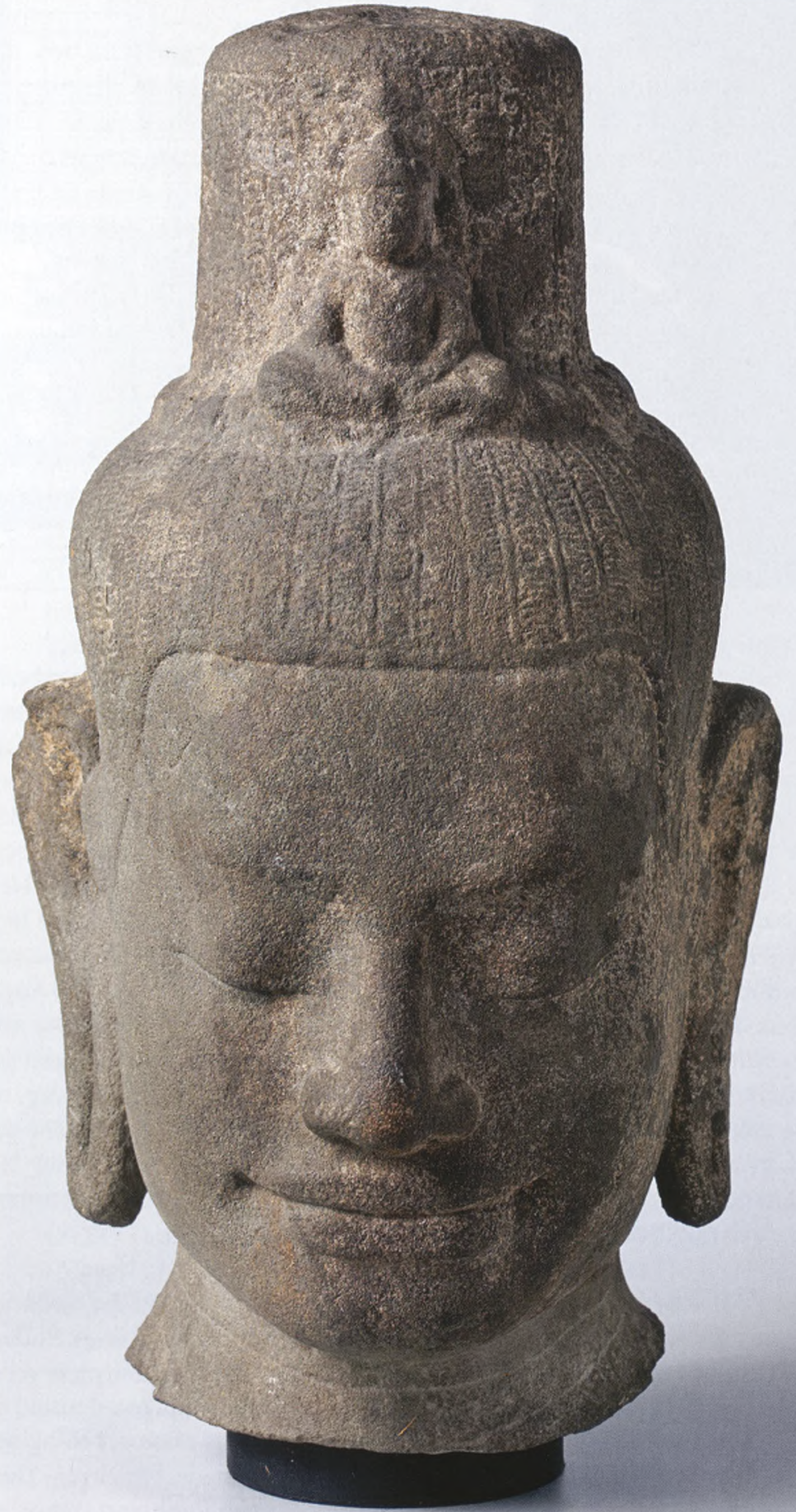

Downloaded from Brill.come4/26/2023 01:16:14AM

via free access 
Fig. 3

Head of Lokesvara, sandstone, Bayon style, Cambodia, 1175-1250, h. $36 \mathrm{~cm}$., w. $20 \mathrm{~cm}$., Rijksmuseum, inv.nr. AK-MAK-226.
These hopes of acquiring some authentic examples of Khmer sculpture for the Society - and the corresponding fears of failing to acquire them obviously troubled Westendorp during the night and he was anxious to return to the depot of the Conservation d'Angkor the following day:

Friday 9th January. Depression. To Angkor Vat, where Bets drew (too) long. Then to the dépot and Marchal, who found it good that we had come to look again, because it had been so dark the first time that everything was difficult to see. I therefore took my 'torch' from Japan with me, that had already done me such good service in the Shoso-in and with which Marchal is delighted. He had never thought of it! At 10.30 Marchal came with a French girl from the post-office in Phnom Penh. Meanwhile, Bets and I walked all around the 'hangar' and looked at the sculptures that stood there. There is a large figure nearby, very beautifully preserved ... I shall ask about it, but probably without success - and so it turned out. Nevertheless, our journey was not at all in vain, because the big head, selected yesterday, and about which we had only moderate feelings, I have been able to exchange for a truly magnificent head, of the highest quality, and which in Paris would definitely cost 20 to 30,000 francs. If Cœdès gives his consent which I do not wish to doubt - then my effort to return to Indochina would be a coup for the Society $!^{5}$

On the following day, his last at Angkor, Westendorp sent a handwritten letter to Georges Coedès (EFEO 3), asking in very polite and polished French for official permission to purchase the three sculptures he had seen in the depot. This was supplemented on the 15 th January by a type-written letter from Henri Marchal (EFEO 4 - the most important of all the letters preserved in the archives of the École française d'Extrême-Orient in Paris), in which he gives details of each of the three sculptures, including a fourth chosen by Westendorp in reserve, in case any of the others were refused. This letter provides the provenance and number at the Conservation d'Angkor of each of the sculptures, as well as a photograph of the two female figures.

\section{The four sculptures}

From these precious details preserved in the archives in Paris, we are now able to determine the exact place of discovery of each of the four sculptures. Three were found at Angkor itself. The head of Lokeśvara (fig. 3), so admired by the Westendorps on their second visit to the depot, was found inside the walls of the great city of Angkor Thom in 1924 (fig. 2, A). It was discovered near the West gate, by the side of the road leading to the Bayon temple. The female figure in the Bayon style (fig. 4), chosen by Westendorp in reserve, was discovered during excavation of the temple of Chau Say Tevoda in 1926. This small temple is situated on the south side of the road leading to the Royal Palace (fig. 2, B). Most importantly, the head with three faces (fig. 5) - the fourth being erased (see 'Straks weer te zien') - was found in 1927 at Ta Prohm, one of the greatest Buddhist temples at Angkor (fig. 2, C). The only sculpture from outside the Angkor region is the female figure in Baphuon style (fig. 6), chosen by Westendorp on his first visit to the depot. It was discovered in Northeastern Cambodia in 1930, in the previously unknown shrine of Prasat Phnom Chon Lu, near the great temple-city of Preah Khan of Kompong Svayaccess 
Fig. $4>$

Female figure, sandstone, Bayon style, Cambodia, 1175-1250, h. $41 \mathrm{~cm}$., w. $16 \mathrm{~cm}$, Rijksmuseum, inv.nr. AK-MAK-228.

Fig. $5 \gg$

Head with four faces, sandstone, Bayon style, Cambodia, 1175-1250, h. $36 \mathrm{~cm}$., w. $27 \mathrm{~cm}$., Rijksmuseum, inv.nr. AK-MAK-227.
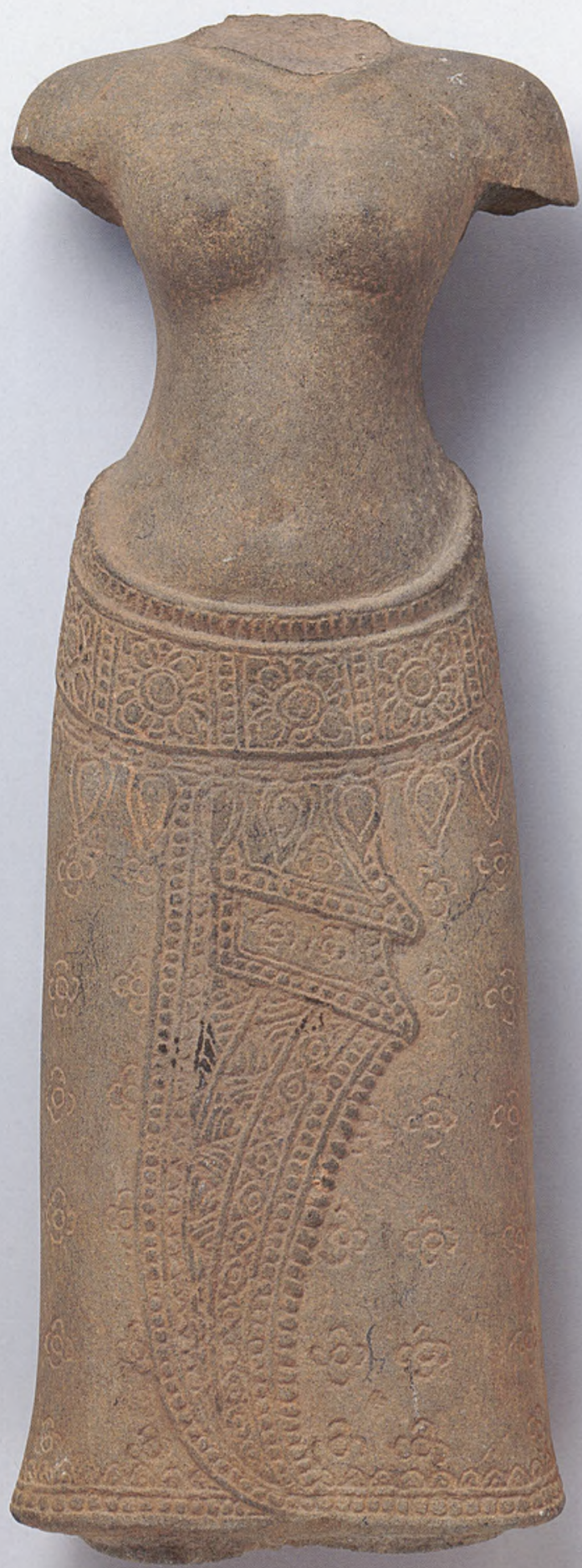


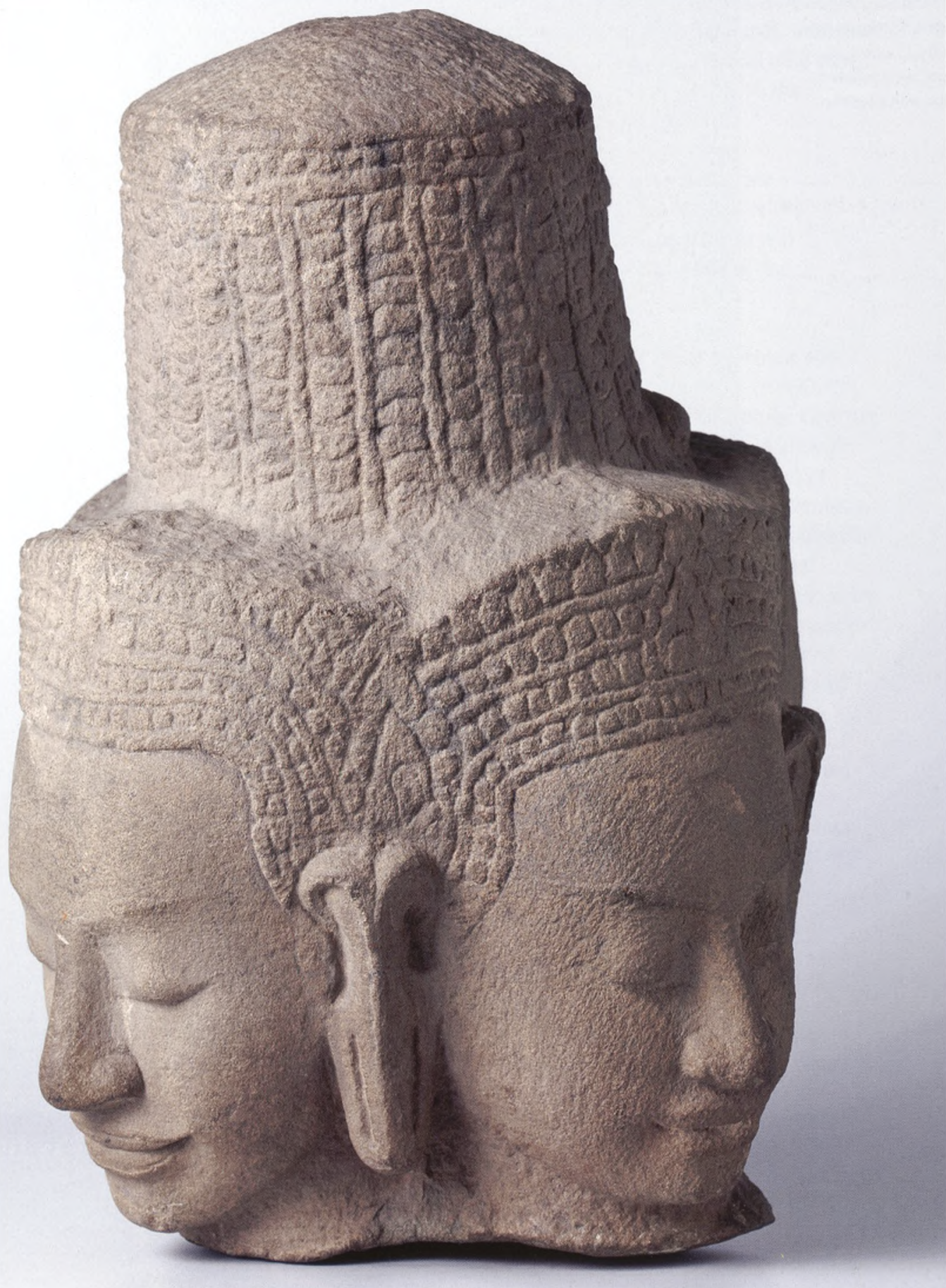


Fig. 6

Female figure,

sandstone, Baphuon style, Cambodia, 10251175 , h. 42 cm., w. 16 cm., Rijksmuseum, inv.nr. AK-MAK-221.

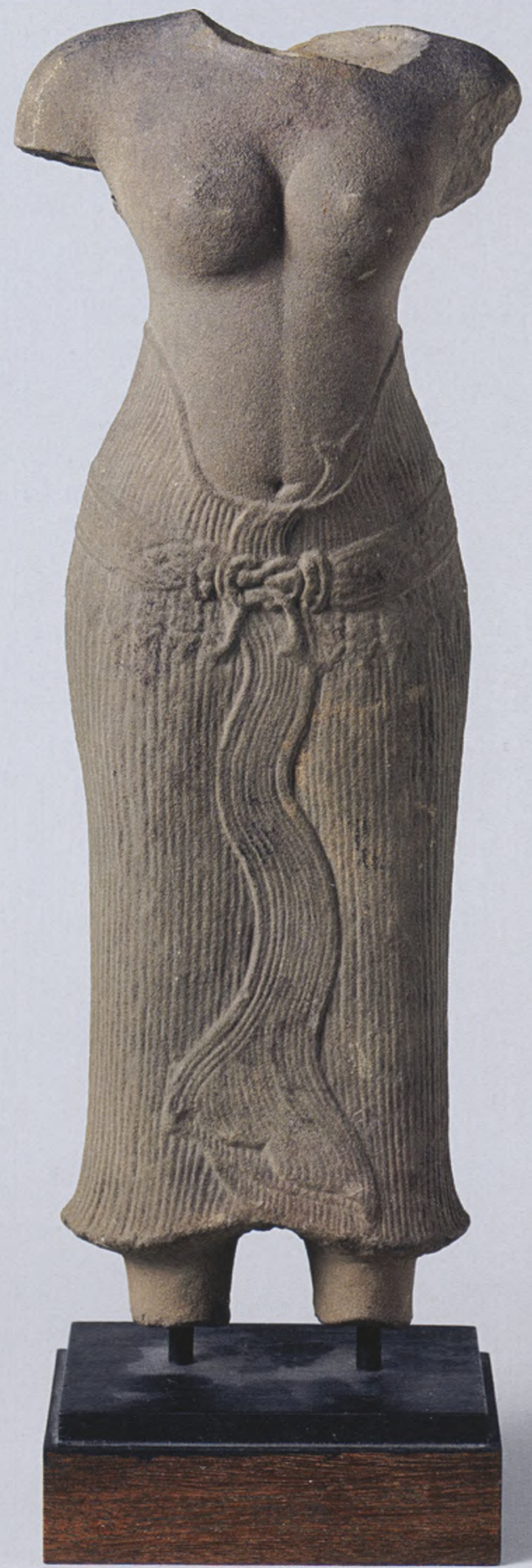

Downloaded from Brill.com04/26/2023 01:16:14AM 
Both Westendorp and Visser returned to the Netherlands in February 1931 and photographs of the Cambodian sculptures were shown to the Committee of the Society on March 31 st. The purchase of the three sculptures was unanimously approved, with the addition that a request should also be made for the fourth sculpture as well. This decision was communicated by letter and telegram (EFEO 5) to Henri Marchal and sent on to George Coedes (EFEO 6). However, due to the exceptional quality of the sculptures, a further confirmation of the sale was requested from the Governor General who gave his formal assent on the 26th May 1931 (EFEO 12). In his letter to the Governor General, Cœdès wrote:

I have the honour of asking you to freely sanction the definitive release of these sculptures, the export of which will not deprive the archaeological heritage of Cambodia of any unique piece, but will contribute to expanding the knowledge of Khmer art in one of the countries of Europe most likely to be interested in it. ${ }^{6}$

The final price agreed for all four sculptures was 2,400 piastres, which was paid in 1932 to the Ecole des Arts Cambodgiens in Phnom Penh (EFEO 15), a college founded alongside the present National Museum by George Groslier (1187-1945) for the training of a new generation of Khmer artists. Although conducted through the colonial framework, institutions and personnel of French Indochina, it is nevertheless hard to be critical of either the intentions of those involved in the purchase or the final outcome of it. While undoubtedly larger and more important sculptures remain on display at the National Museum in Phnom Penh and at Angkor itself, the four sculptures acquired by Westendorp during his Asian tour nevertheless retain their own significance as part of the early history of Khmer art in the Netherlands, a significance enhanced not only by their sculptural quality but also by the knowledge of their archaeological provenance.

- William Southworth is curator of Southeast Asian Art at the Rijksmuseum in Amsterdam. He completed his doctorate in London (2001) on the early Champa culture of central Vietnam and has since worked in Germany, the Netherlands and Cambodia. $\mathrm{He}$ is interested in inter-cultural connections and exchange throughout Southeast Asia and the relationship between history, art and archaeology.

\section{Literature}

Maartje Draak, 'Het Rode Boekje van Mevrouw Westendorp', Aziatische Kunst 15-4 (1985), pp. 9-12.

Maartje Draak, 'Chronicle of the Vereniging van Vrienden der Aziatische Kunst', in:

P. Lunsingh Scheurleer (ed.), Asiatic art in the Rijksmuseum, Amsterdam, Amsterdam, 1985, pp. 9-27.

Menno Fitski, 'De Blauwe Boekjes van Mr. H.K. Westendorp', Aziatische Kunst 38-4 (2008), pp. 39-47.

Jacques Gaucher, 'Angkor Thom, une utopie réalisée? Structuration de l'espace et modele indien d'urbanisme dans le Cambodge ancien', Arts Asiatiques 59 (2004), pp. 58-86.

\section{DOCUMENTATION}

École française d'Extrême-Orient, Paris, Archives section R.10.5, 'Subdivision ventes; cessions des sculptures khmères à $M$. Westendorp, Directeur du Musée royal d'Amsterdam 1930-1932': 
1. (no. 247) Telegram from H. Marchal ('Conservateur Angkor') to G. Cœdès ('Direc[teur de l'Ecole française d'Extrême-]Orient'), Siem Reap to Hanoi, 4th December 1930.

la. (no. 2763) Letter from G. Cœedès ('Le Directeur de l'Ecole française d'ExtrêmeOrient') to P. Pasquier ('Monsieur le Gouverneur Général de l'Indochine'), Hanoi, 5th December 1930.

2. (no. 4229 sa.) Letter from P. Pasquier ('Le Gouverneur Général de l'Indochine') to G. Cœdès ('Monsieur le Directeur de l'Ecole française d'Extrême-Orient'), Hanoi, 20th December 1930.

3. Letter from H.K. Westendorp to G. Cœdès ('Directeur de l'Ecole d'Extrême-Orient'), from Angkor to Hanoi, 10th January 1931.

3a. Letter from R. Koechlin ('Ministère de l'Instruction Publique et des Beaux-Arts, Conseil des Musées Nationaux) to G. Cœedès ('Monsieur le Directeur'), Paris, 28th April 1930.

4. (no. 17) Letter from $\mathrm{H}$. Marchal ('Le Conservateur des monuments du groupe d'Angkor') to G. Cœdès ('Monsieur le Directeur de l'Ecole française d'ExtrêmeOrient'), from Siem Reap to Hanoi, 15th January 1931.

5. Letter from H.K. Westendorp to H. Marchal ('Le Conservateur d'Angkor'), from Amsterdam to Siem Reap, 1st April 1931.

6. Letter from H. Marchal to G. Cœedes ('Mon cher ami'), Siem Reap to Hanoi, 21st April 1931.

12. (no. 3079) Letter from G. Cœdès ('Le Directeur de l'Ecole française d'ExtrêmeOrient') to P. Pasquier ('Monsieur le Gouverneur Général de l'Indochine'), Hanoi, 28th April 1931; approved and undersigned, 26th May 1931.

15. (no. 200) Letter from G. Groslier ('Le Directeur des Arts Cambodgiens') to G. Cœedès ('Monsieur le Directeur de l'Ecole française d'Extrême-Orient'), Phnom Penh to Hanoi, 2nd April 1932.

\section{Notes}

1. Acknowledgements.

I am deeply indebted to my colleague Menno Fitski, who has worked on the diaries of H.K. Westendorp for many years and who kindly supplied all of the references and quotations from Westendorp's journal that I have used in this article. In addition, my sincere thanks are due to the directorate and staff of the EFEO in Paris. To the Director, Franciscus Verellen, and to the Chief Librarian, Cristina Cramerotti, for their permission to consult and photograph the relevant letters in the archives; and to Saming Prasomsouk in the library, and Isabelle Poujol and Christine Hawixbrock in the photographic library, for their generous help during my visit there in October 2011. Special thanks are due to Pierre-Yves Manguin, Director of Studies, for advising me on where I should look and who I should contact in advance, and to Ian Glover, formerly of the Institute of Archaeology (UCL) London, who first suggested consulting the archives based on his own successful research there in the 1990 s.

2. See 'Chronicle of the Vereniging', Draak 1985: 12.

3. This part of their journey, concerning their stay in Japan, has been reconstructed from the private journals of both Betsy Westendorp-Osieck ('Het rode boekje': Draak 1985) and Herman Karel Westendorp ('De blauwe boekjes': Fitski 2008: 39-47).

4. "Donderd[ag]. 8 Januari. Marchal komt ons om 7 uur halen. We gaan met hem naar Bayon, en zien thans veel meer, ook de groote gezichten van dichtbij. Foto's, echter is de zon nog niet sterk. Vervolgens naar Prah Khan, waar wij rondklauteren naar de binnenste sanctuaire. Naar Porte la Victoire 2 foto's, denk alleen de laatste goed. Vervolgens naar het dépot. Hoopjes koppen, torzen etc. De mooiste zijn naar Parijs, of gereserveerd voor Pnom Penh en Hanoi, maar ik zoek toch een 3 tal stuks uit, een groote kop, een stuk met 3 koppen, en een figuurtje - die ik hoop te krijgen voor Museum. Dat zou wat zijn!!" 
5. "Vrijdag 9 Januari. Depressie. Naar Angkor Vat, waar Bets (te) lang teekent. Daarna naar dépot Marchal, die goed gevonden heeft dat wij er nog eens kwamen kijken, daar het de eerste maal zoo donker was, dat alles slecht was te zien. Ik neem daarom mijn 'toorts' uit Japan mee, die mij in de Shoso-in reeds zulke goede diensten bewees [marge] en waar M. verrukt van is. Hij had er nog nooit aan gedacht! Om $1 / 211$ komt Marchal met een fransche juffrouw van de post in Pnom Penh. Intusschen hadden Bets en ik al om de 'hangar' heen geloopen en de sculpturen die daar staan bekeken. Er is een groote figuur bij, heel mooi bewaard... Ik zal erom vragen, maar het zal wel niet lukken, - en zoo komt het ook uit. Toch is onze tocht allerminst vergeefs geweest, want de groote kop, gisteren uitgezocht, en die ons maar matig beviel, heb ik kunnen ruilen tegen een waarlijk prachtige kop, van den allerbeste kwaliteit, en die in Parijs zeker frs 20 a 30.000 zou kosten. Als Coedès zijn toestemming geeft, - waaraan ik niet wil twijfelen, - dan is mijn effort om naar Indochina terug te gaan, een bof voor de Vereeniging!"

6. “... j'ai l'honneur de vous prier de bien vouloir sanctionner définitivement la cession de ces sculptures dont l'aliénation ne privera le patrimoine archéologique du Cambodge d'aucune pièce unique, et contribuera à répandre la connaissance de l'art khmer dans un des pays d'Europe le mieux placé pour s'y intéresser." 